\title{
Levator Palpebrae Biopsy and Diagnosis of Progressive External Ophthalmoplegia
}

\author{
Gerald Pfeffer, Paula J. Waters, John Maguire, Hilary D. Vallance, V. A. Wong, \\ Michelle M. Mezei
}

\begin{abstract}
Background: Progressive external ophthalmoplegia (PEO) is a mitochondrial myopathy of ocular muscles. Diagnostic investigation usually involves limb skeletal muscle biopsy and molecular genetic studies, although diagnostic yield tends to be low. The purpose of this study was to evaluate the diagnostic yield obtained by analysis of levator palpebrae (LP) muscle tissue. Methods: This is a clinicopathologic study of 8 patients with a diagnosis of PEO, who had LP muscle biopsies as part of oculoplastic procedures. Six of these patients also had limb muscle biopsies. Histopathology, electron microscopy and genetic studies were performed. Results: Diagnostic histopathologic findings were present in 4/6 quadriceps biopsies, and 7/8 LP biopsies. Genetic testing on DNA extracted from LP muscle revealed abnormalities in 4 patients. Conclusion: In patients whose LP muscle demonstrate both genetic defects and histopathological abnormalities, the diagnosis of PEO can be confirmed without limb muscle biopsy. Patients having LP resection during oculoplastics procedures for treatment of ptosis may therefore be able to avoid a separate procedure for limb muscle biopsy. Further study is required to determine the specificity of these findings.
\end{abstract}

RÉSUMÉ: Biopsie du muscle releveur de la paupière et diagnostic de l'ophtalmoplégie externe progressive. Contexte : L'ophtalmoplégie externe progressive (OEP) est une myopathie mitochondriale des muscles oculaires. L'évaluation diagnostique comprend une biopsie d'un muscle squelettique au niveau d'un membre et des études de génétique moléculaire. Cependant, le taux de diagnostic demeure bas. Le but de cette étude était d'évaluer le taux de diagnostic obtenu au moyen de l'analyse du tissu du muscle releveur de la paupière (RP). Méthode : Il s'agit d'une étude clinicopathologique effectuée chez 8 patients, chez qui un diagnostic d'OEP avait été posé, et qui ont subi une biopsie du RP dans le cadre d'une chirurgie oculoplastique. Six de ces patients ont également subi une biopsie d'un muscle au niveau d'un membre. Des études anatomopathologiques, de microscopie électronique et génétiques ont été réalisées. Résultats : Le diagnostic a été établi en anatomopathologie sur 4 des 6 biopsies du quadriceps et sur 7 des 8 biopsies du RP. Des anomalies ont été détectées par des tests génétiques effectués sur de l'ADN extrait du muscle RP chez 4 patients. Conclusion : Chez les patients chez qui des défauts génétiques et des anomalies anatomopathologiques du muscle RP ont été mis en évidence, le diagnostic d'OEP peut être confirmé sans biopsie musculaire au niveau d'un membre. Chez les patients qui subissent une résection du RP pendant une oculoplastie pour traiter une ptose, la biopsie musculaire au niveau d'un membre peut donc être évitée. Des études plus poussées devront être faites pour déterminer la spécificité de ces observations.

Can J Neurol Sci. 2012; 39: 520-524

Progressive external ophthalmoplegia (PEO) is a mitochondrial myopathy of the ocular muscles. Like other mitochondrial diseases, PEO is difficult to diagnose because of variable clinical presentation and the absence of reliable noninvasive tests. Yield on genetic studies is limited by extensive genetic heterogeneity, and some patients have no abnormalities on muscle biopsy. ${ }^{1}$ In consideration of the above-mentioned challenges in the diagnosis of PEO, new diagnostic approaches must be sought to improve diagnostic accuracy. Progressive external ophthalmoplegia always affects the extraocular muscles and the levator palpebrae (LP), therefore it is possible that histologic and ultrastructural abnormalities are more apparent in affected tissue. This retrospective clinicopathologic study evaluated whether LP biopsies (obtained during oculoplastic procedures for treatment of ptosis) provided comparable diagnostic yield for PEO compared with limb skeletal muscle biopsies. 


\section{METHODS}

This study is a retrospective chart review of patients from the Adult Metabolic Diseases Clinic in Vancouver, Canada. Institutional research ethics board approval was obtained. For inclusion patients were above 19 years-of-age with a diagnosis of PEO, who also had a LP muscle biopsy. A diagnosis of PEO required characteristic clinical features, exclusion of alternative aetiologies (including negative OPMD genetic testing and AchR antibodies), with a diagnostic muscle biopsy and/or pathogenic genetic abnormality. Findings on ocular examination were confirmed in consultation with a neuro-ophthalmologist. The clinic database was consulted and identified 43 consecutive PEO patients who had been assessed in the clinic from 2000-2008. Of these, six patients had muscle biopsies from both limb muscle and LP muscle, while two patients had LP biopsy only. The remainder of the patients were excluded.

The eight charts which were included were reviewed in their entirety with attention to age, age at biopsy, time between muscle biopsies, histopathology results, electron microscopy results, and genetic testing results. Levator palpebrae muscle tissue was obtained via the following procedure: Dissection was made through the skin and orbicularis muscle, to expose the levator muscle and aponeurosis. The levator muscle complex was carefully disinserted from the tarsal plate and after the muscle was advanced and sutured to the tarsal plate to repair the ptosis, the redundant part of the levator muscle was resected and sent for histologic identification and appropriate genetic testing. Histopathologic studies included periodic acid-Schiff reaction, modified Gomori trichrome (GTC), succinate dehydrogenase (SDH), cytochrome c oxidase (COX), oil red $\mathrm{O}$ and nicotinamide adenine dinucleotide tetrazolium reductase (NADH) in all cases

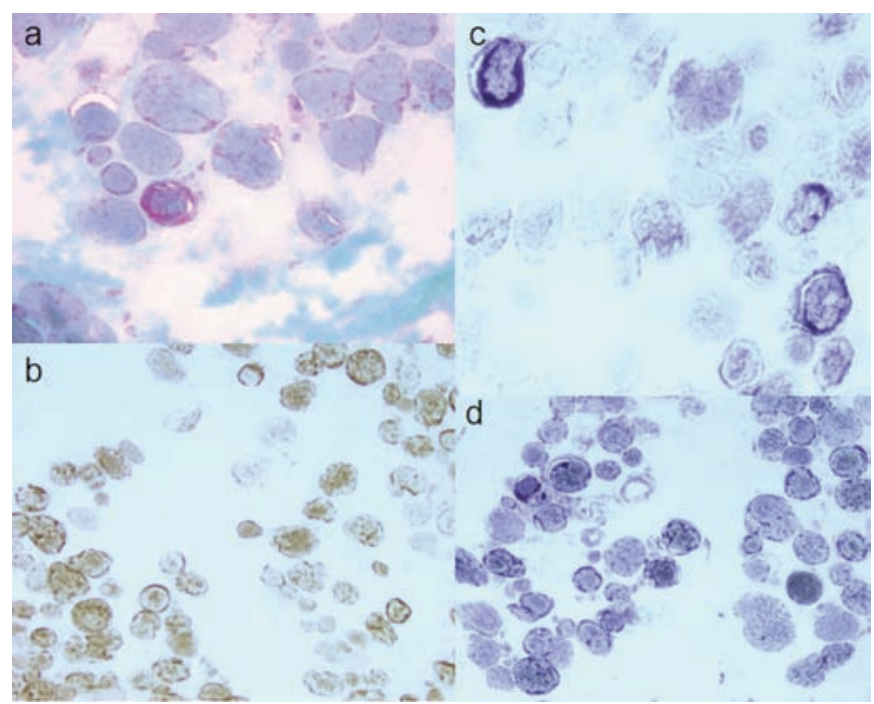

Figure 1: Histopathologic abnormalities on levator palpebrae muscle in PEO, from Patient 5: (a) Gomori trichrome demonstrates ragged red fibres and subsarcolemmal staining abnormalities. (b) cytochrome $c$ oxidase (COX) assay showing COX-negative fibres, and abnormal subsarcolemmal staining (ragged brown fibres). SDH assay (c) and $N A D H$ assay $(d)$ reveal subsarcolemmal abnormalities. The findings are consistent with mitochondrial myopathy. where samples were sufficient. Histopathology and electron microscopy (EM) were considered diagnostic of mitochondrial disease according to the interpretation of one of the authors (JM), who is a neuropathologist with expertise in muscle disease, and who re-reviewed the images blinded to patient identity.

Genetic testing for mtDNA deletions was performed using long-range polymerase chain reactions (PCR), and confirmed with Southern blot. Several common mtDNA point mutations (m.A3243G, m.T3271C, m.T3271delT, and m.A8344G) were tested with restriction fragment length polymorphism (RFLP) assays. The above mtDNA tests were all performed on muscle; from limb and/or levator, depending on sample availability.

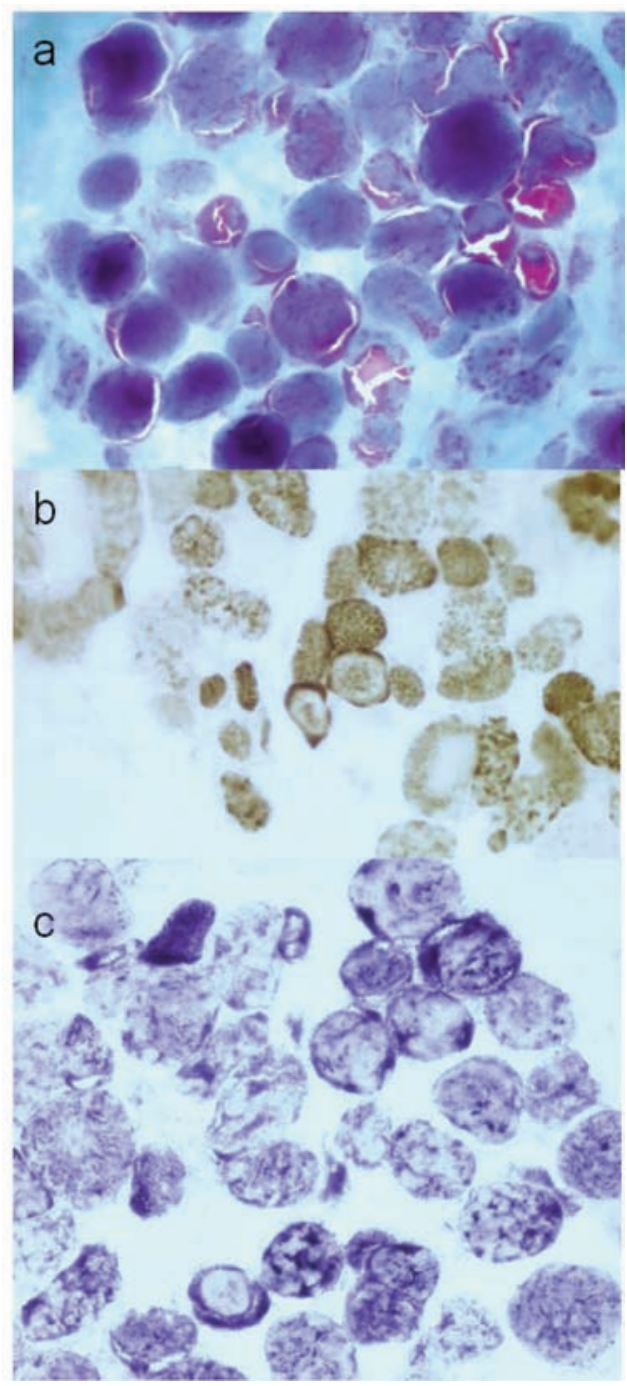

Figure 2: Histopathologic abnormalities on levator palpebrae muscle in PEO, from Patient 7: (a) Gomori trichrome demonstrates numerous ragged red fibres and subsarcolemmal staining abnormalities. (b) cytochrome c oxidase (COX) assay showing COX-negative fibres, and abnormal subsarcolemmal staining (ragged brown fibres). SDH assay (c) reveals subsarcolemmal abnormalities. The findings are consistent with mitochondrial myopathy. 
Table: Muscle pathology and genetic testing results

\begin{tabular}{|c|c|c|c|c|c|c|c|c|}
\hline \multirow{2}{*}{$\begin{array}{l}\text { Number } \\
\text { in } \\
\text { series/ } \\
\text { sex }\end{array}$} & \multirow{2}{*}{$\begin{array}{l}\text { Clinical } \\
\text { features }\end{array}$} & \multirow{2}{*}{$\begin{array}{l}\text { Age at } \\
\text { limb } \\
\text { biopsy } \\
\text { (years) }\end{array}$} & \multirow{2}{*}{$\begin{array}{l}\text { Age at } \\
\text { levator } \\
\text { biopsy } \\
\text { (years) }\end{array}$} & \multicolumn{2}{|c|}{ Pathological features on muscle biopsy } & \multicolumn{3}{|c|}{ Results of genetic testing } \\
\hline & & & & Limb & Levator & Limb & Levator & Blood \\
\hline $1 \mathrm{M}$ & $\mathrm{PEO}, \mathrm{M}$ & 33 & 34 & $\begin{array}{l}\text { RRF, cox-neg fibres, and } \\
\text { subsarcolemmal } \\
\text { abnormalities on SDH. }\end{array}$ & $\begin{array}{l}\text { Numerous RRF. } \\
\text { Subsarcolemmal mitochondrial } \\
\text { aggregates on EM. Some } \\
\text { atrophic fibres present. }\end{array}$ & $\begin{array}{l}\text { Single } 5 \mathrm{~kb} \text { mtDNA } \\
\text { deletion identified: } \\
\text { approx } 10 \% \\
\text { heteroplasmy } \\
\text { (Southern blot) }\end{array}$ & $\begin{array}{c}\text { No sample } \\
\text { available }\end{array}$ & $\begin{array}{l}\text { No testing } \\
\text { performed }\end{array}$ \\
\hline $2 \mathrm{~F}$ & PEO, D & 52 & 53 & $\begin{array}{c}\text { Cox-neg fibres present } \\
\text { with some subsarcolemmal } \\
\text { abnormalities. GTC } \\
\text { nonspecific. EM } \\
\text { nonspecific. }\end{array}$ & $\begin{array}{l}\text { Histopathology specimen } \\
\text { contained end-stage muscle } \\
\text { atrophy (non-diagnostic). EM } \\
\text { demonstrated subsarcolemmal } \\
\text { accumulations of numerous } \\
\text { abnormally large mitochondria, } \\
\text { with abnormal arrangement of } \\
\text { cristae. (Refer to Figure 3) }\end{array}$ & $\begin{array}{c}\text { Single } 3.8 \mathrm{~kb} \\
\text { mtDNA deletion } \\
\text { identified: approx } \\
30 \% \text { heteroplasmy } \\
\text { (Southern blot) }\end{array}$ & $\begin{array}{c}\text { Single } 3.8 \mathrm{~kb} \\
\text { mtDNA deletion } \\
\text { identified (long } \\
\text { PCR) }\end{array}$ & $\begin{array}{l}\text { No testing } \\
\text { performed }\end{array}$ \\
\hline $3 \mathrm{~F}$ & $\begin{array}{l}\text { PEO, PM, } \\
\text { PN }\end{array}$ & 42 & 44 & $\begin{array}{l}\text { Abnormal subsarcolemmal } \\
\text { staining on GTC and } \\
\text { scattered RBLF on SDH. }\end{array}$ & $\begin{array}{l}\text { RRF, RBRF, RBLF, Cox-neg } \\
\text { fibres. Nondiagnostic EM } \\
\text { (muscle atrophy only). }\end{array}$ & $\begin{array}{c}\text { No sample } \\
\text { available }\end{array}$ & $\begin{array}{l}\text { Multiple mtDNA } \\
\text { deletions (long } \\
\text { PCR) }\end{array}$ & $\begin{array}{c}\text { Heterozygous } \\
\text { p.T251I and } \\
\text { p.P587L } \\
\text { mutations in } \\
\text { POLG1. }\end{array}$ \\
\hline $4 \mathrm{~F}$ & PEO, M, D & 50 & 52 & $\begin{array}{l}\text { GTC normal, single Cox- } \\
\text { neg fibre. (Non-diagnostic) }\end{array}$ & $\begin{array}{l}\text { Numerous RRF, RBLF, RBRF, } \\
\text { Cox-neg fibres. }\end{array}$ & $\begin{array}{l}\text { No rearrangements } \\
\text { (long PCR), or } \\
\text { deleterious } \\
\text { mutations detected } \\
\text { (mtDNA genome } \\
\text { sequencing). } \\
\end{array}$ & $\begin{array}{l}\text { No sample } \\
\text { available }\end{array}$ & $\begin{array}{l}\text { No testing } \\
\text { performed }\end{array}$ \\
\hline $5 \mathrm{~F}$ & PEO, M, D & 50 & 54 & $\begin{array}{c}\text { Minimal nonspecific } \\
\text { changes. (Non-diagnostic) }\end{array}$ & $\begin{array}{l}\text { Presence of RRF, RBLF, } \\
\text { RBRF, Cox-neg fibres. (Refer } \\
\text { to Figure 1) }\end{array}$ & $\begin{array}{l}\text { No abnormality } \\
\text { detected }\end{array}$ & $\begin{array}{l}\text { No rearrangements } \\
\text { (long PCR) or } \\
\text { deleterious } \\
\text { mutations detected } \\
\text { (mtDNA genome } \\
\text { sequencing) } \\
\end{array}$ & $\begin{array}{l}\text { No testing } \\
\text { performed }\end{array}$ \\
\hline $6 \mathrm{~F}$ & $\begin{array}{l}\text { PEO, PM, } \\
\text { D }\end{array}$ & 57 & 58 & $\begin{array}{l}\text { RRF, RBLF, and cox-neg } \\
\text { fibres. }\end{array}$ & $\begin{array}{c}\text { Presence of RRF and Cox-neg } \\
\text { fibres. Increased } \\
\text { subsarcolemmal staining on } \\
\text { SDH/NADH. Muscle atrophy } \\
\text { present. EM with increased } \\
\text { number of mitochondria, of } \\
\text { very large size having } \\
\text { concentric lamellar internal } \\
\text { architecture. }\end{array}$ & $\begin{array}{l}\text { No sample } \\
\text { available }\end{array}$ & $\begin{array}{l}\text { No rearrangements } \\
\text { (long PCR) or } \\
\text { mutations at } \\
\text { positions } 3243 \text {, } \\
3271 \text {, or } 8344 \text {. }\end{array}$ & $\begin{array}{l}\text { No testing } \\
\text { performed }\end{array}$ \\
\hline $7 \mathrm{M}$ & PEO, PN, D & $\mathrm{n} / \mathrm{a}$ & 47 & $\mathrm{n} / \mathrm{a}$ & $\begin{array}{l}\text { Majority of fibres are RRF, } \\
\text { RBLF and Cox-neg. (Refer to } \\
\text { Figure 2) EM with } \\
\text { subsarcolemmal accumulations } \\
\text { of mitochondria, with } \\
\text { intramitochondrial inclusions. }\end{array}$ & $\begin{array}{l}\text { No biopsy } \\
\text { performed }\end{array}$ & $\begin{array}{c}\text { Single } 7.3 \mathrm{~kb} \\
\text { mtDNA deletion } \\
\text { identified: approx } \\
75 \% \text { heteroplasmy } \\
\text { (Southern blot) }\end{array}$ & $\begin{array}{l}\text { No testing } \\
\text { performed }\end{array}$ \\
\hline $8 \mathrm{M}$ & PEO, PN, S & $\mathrm{n} / \mathrm{a}$ & 72 & $\mathrm{n} / \mathrm{a}$ & $\begin{array}{l}\text { Extensive fibrous tissue. Few } \\
\text { fibres are present but these } \\
\text { demonstrate presence of RRF, } \\
\text { and increased subsarcolemmal } \\
\text { staining on NADH/SDH. EM } \\
\text { with pleiomorphic } \\
\text { mitochondria having abnormal } \\
\text { architecture and cristae. }\end{array}$ & $\begin{array}{l}\text { No biopsy } \\
\text { performed }\end{array}$ & $\begin{array}{l}\text { Single deletion of } \\
7.2 \mathrm{~kb} \text { (long PCR), } \\
\text { from nucleotide } \\
\text { positions } 8588 \text { to } \\
15758 \text { (mtDNA } \\
\text { sequencing) }\end{array}$ & $\begin{array}{c}\text { POLG1 } \\
\text { sequencing: no } \\
\text { pathogenic } \\
\text { abnormalities }\end{array}$ \\
\hline
\end{tabular}

$\mathrm{M}=$ male; $\mathrm{F}=$ female; $\mathrm{PEO}=$ ptosis and ophthalmoparesis; $\mathrm{M}=$ migraine; $\mathrm{D}=$ dysphagia; $\mathrm{PM=proximal} \mathrm{myopathy;}$ $\mathrm{PN}=$ peripheral neuropathy; $\mathrm{S}=$ sensorineural hearing loss; RRF=ragged red fibres; $\mathrm{RBLF}=$ ragged blue fibres; $\mathrm{RBRF}=$ ragged brown fibres; Cox-neg=cytochrome $\mathrm{c}$ oxidase negative; $\mathrm{EM}=$ electron microscopy; $\mathrm{k}=\mathrm{kilobase}$ pairs; mtDNA=mitochondrial DNA; GTC=gomori trichrome; $\mathrm{SDH}=$ succinyl dehydrogenase; $\mathrm{NADH}=$ nicotinamide adenine dinucleotide tetrazolium reductase; POLG1=gene encoding polymerase-gamma1; PCAR=polymerase chain reaction.

Testing for mutations in POLG1, SLC25A4 (a.k.a: ANT), C10orf2 (a.k.a: TWINKLE) was performed in some cases, using DNA extracted from blood.

\section{RESULTS}

Please refer to the Table for details. Of the six patients with biopsies from both locations, pathological features of mitochondrial myopathy were present in 4/6 limb biopsies and 5/6 LP biopsies. Examples of LP muscle histopathology are demonstrated in Figures 1-2. The LP biopsy in the one case which was not diagnostic contained mostly atrophic tissue, although EM in this sample still was compatible with mitochondrial myopathy (MM) (refer to Figure 3). Of six LP samples available for mtDNA testing, three revealed single mtDNA deletions, while one showed multiple mtDNA deletions attributable to POLG1 gene defects.

\section{DisCUSSION}

This study demonstrates that a diagnosis of PEO can be achieved using combined histochemical assays, EM, and genetic analysis on LP muscle tissue. In the cases of Patients 2, 7, and 8, genetic abnormalities were detected on DNA from LP muscle. 
Taken together with the clinical picture and histopathologic abnormalities, the diagnosis of PEO could have been confirmed without the results of the quadriceps biopsies (note that DNA from muscle is required given that the mtDNA abnormalities are usually not detectable in leucocyte DNA). In Patient 3 genetic testing demonstrated multiple mtDNA deletions, which prompted further testing for nuclear gene mutations which cause PEO, and ultimately POLGl mutations were identified. Thus, for half of the patients in this series, a confirmed diagnosis of PEO was possible from the LP muscle results alone. We have also separately reported a case of PEO in which quadriceps muscle was nondiagnostic, but LP muscle demonstrated ragged red fibres (RRFs) and cytochrome c oxidase (COX) -negative fibres. A single large-scale mtDNA deletion confirmed the diagnosis of PEO. ${ }^{2}$ In cases such as these, where LP muscle histopathology reveals findings of MM, and LP muscle DNA testing demonstrates causative mutations for PEO, further diagnostic work-up with a limb muscle biopsy may be redundant. Therefore, we suggest that patients who are having LP muscle resection for ptosis should have their diagnostic investigations performed on LP muscle, and may avoid the additional procedure of a limb muscle biopsy.

There are limitations to the use of LP muscle. The small quantity of tissue makes respiratory chain enzyme analysis impossible, although in our experience these studies nearly always overlap with normal ranges in adult-onset $\mathrm{PEO}^{1}$. Furthermore, the biopsy may contain significant quantities of atrophic muscle, rendering interpretation difficult (as was the case for Patient 2 in this series). It should also be noted that there may not be sufficient tissue remaining for DNA extraction once pathology studies have been performed, as was the case for two of our patients. Further study will also need to be performed to confirm the reliability of long PCR testing on DNA from LP muscle; this is because prior study suggests age-related mtDNA deletions accumulate at a higher rate in ocular muscle compared with limb skeletal muscle. ${ }^{3}$ This means that, in theory, multiple mtDNA deletions may be observed from LP muscle DNA in patients who do not have a mutation in a nuclear-encoded mtDNA maintenance gene. However, this was not observed in our patients, and the only patient with multiple mtDNA deletions had POLG1 mutations. Another important limitation of this study was lack of control LP muscle for comparison. The pathological features may therefore be nonspecific. Control data for normal LP muscle and in other disorders causing ptosis will need to be collected and published. Until this is done, histopathologic features of MM on LP muscle cannot be considered sufficient to diagnose PEO, unless the extracted DNA also identifies a mtDNA abnormality causative of PEO. Finally, it is important to mention that not all patients will be eligible for LP muscle biopsy, since not all patients require oculoplastics procedures for ptosis; these patients would still need a limb muscle biopsy for their diagnostic workup. Taken together, these limitations caution that investigations on LP muscle will not be able to confirm a diagnosis of PEO in all patients, but we maintain that for some it may obviate a separate procedure for limb muscle biopsy.

Patients who have severe ptosis must be carefully selected for the correct oculoplastics procedure, and this affects the ability to obtain LP muscle for analysis. In patients with severe ptosis and

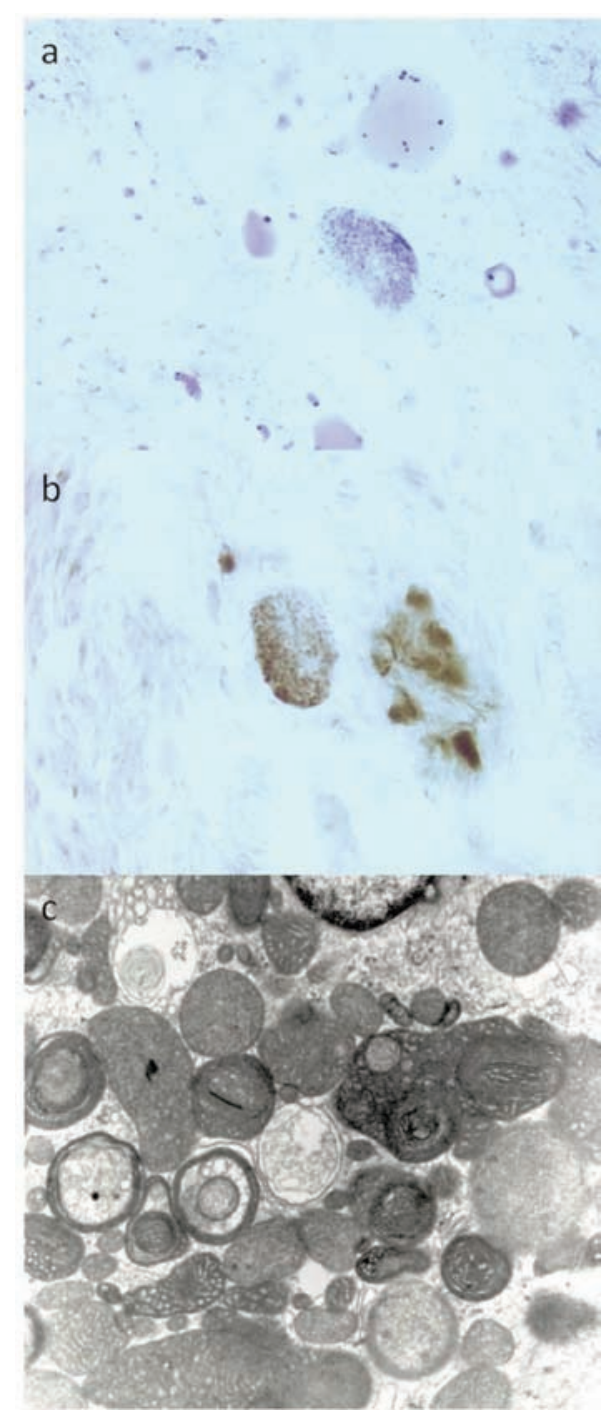

Figure 3: This figure demonstrates potential pitfalls of pathologic analysis with levator palpebrae muscle (from Patient 2). Gomori trichrome (a) and cytochrome coxidase (b) assays provide no diagnostic information because the sample consists almost entirely of end-stage atrophic tissue. However, electron microscopic analysis of the same sample (c) at 21600x magnification demonstrated significantly increased mitochondrial number, pronounced pleiomorphism in size and shape, numerous intramitochondrial inclusions, with some degenerative mitochondrial profiles. These features are consistent with mitochondrial myopathy, which was confirmed with the presence of a single large-scale mtDNA deletion.

with a levator function of $4 \mathrm{~mm}$ or less, a frontalis sling is usually preferred to repair the ptosis. This is done to allow the frontalis muscle to lift the lids directly. Because this procedure does not involve exposure of the levator muscle, a biopsy is not normally done in these cases. Although a biopsy is still possible, it would cause significant swelling and therefore affect the success of the sling surgery.

The majority of patients with PEO have less severe ptosis on initial diagnosis. If the levator muscle has greater than $4 \mathrm{~mm}$ 
function, a levator advancement and resection is preferred to repair the ptosis in most cases. ${ }^{4}$ With this surgery the levator muscle can be easily biopsied to confirm the diagnosis of myogenic ptosis. The patients in this paper all had significant ptosis with the upper lid encroaching close to the visual axis, but because their levator function was still fair, a levator resection was preferred as first line surgery.

We did not attempt to compare severity of histopathologic findings between limb and LP muscle, due to the lack of availability of some assays in some of the patients, and due to uncertainty in interpretation of the severity of LP pathology given the lack of normal data on LP muscle. Nonetheless, histopathologic findings have been compared between LP and limb muscle in a prior study of 11 patients with PEO. ${ }^{5}$ More COX-deficient fibres were present in LP tissue, and these findings were quantified, and statistically significant. However, the time interval between limb and LP biopsy was not mentioned, therefore it is unclear whether disease progression might have accounted in part for these findings.

One prior study assessed EM analysis of LP biopsy in PEO. Wabbels included EM examination for 24 patients with PEO, congenital ptosis, or early-onset acquired ptosis. ${ }^{6}$ Findings in PEO patients were similar to those with other causes of ptosis. However, this study was limited by a lack of histological or molecular genetic data, and in this regard it is uncertain whether some or all of the patients with congenital or acquired ptosis may have also had a type of MM (or whether some of the PEO patients had been misdiagnosed). In our study, we demonstrate that EM revealed characteristic abnormalities of MM in 5/7 patients, including one patient for whom histopathology had revealed only end-stage muscle atrophy.

Other types of ocular tissue have been studied in PEO. Orbicularis oculi muscle has been evaluated in two studies. Eshaghian described findings in biopsies from 10 PEO patients compared with 28 controls. ${ }^{7}$ The RRFs were present in PEO and control patients, although more abundant in the PEO group. However, half of the subjects were above 50, potentially explaining the RRFs in the control biopsies. Almousa reported orbicularis oculi biopsy findings from ten PEO patients although diagnosis was not confirmed with limb muscle biopsy or genetic studies. ${ }^{8}$ Histochemical analysis was consistent with MM in 9/10 patients. Medial rectus tissue has been studied in individual case reports with PEO, which included EM and genetic analysis ${ }^{9,10}$.

We conclude that in patients having LP resection for ptosis, LP muscle can be used for pathologic and genetic investigations, and in some cases may eliminate the need for a separate muscle biopsy in the diagnosis of PEO.

\section{ACKNOWLEDGEMENTS}

GP is the recipient of funding from the Clinician Investigator Program from the University of British Columbia, and of a Bisby fellowship from the Canadian Institutes of Health Research.

The authors thank Jayoung Janet Lee and the laboratory of Dr. Helene CF Cote who performed genetic analysis on some of the samples. For assistance with clinical records and database access, we thank Margaret O'Reilly, Anna Koochin, and staff of the Adult Metabolic Diseases Clinic.

\section{REFERENCES}

1. Pfeffer G, Sirrs S, Wade NK, Mezei MM. Multisystem disorder in late-onset chronic progressive external ophthalmoplegia. Can J Neurol Sci. 2011 Jan;38(1):119-23.

2. Pfeffer G, Cote HC, Montaner JS, Li CC, Jitratkosol M, Mezei MM. Ophthalmoplegia and ptosis: Mitochondrial toxicity in patients receiving HIV therapy. Neurology. 2009 Jul 7;73(1): $71-2$.

3. Yu-Wai-Man P, Lai-Cheong J, Borthwick GM, et al. Somatic mitochondrial DNA deletions accumulate to high levels in aging human extraocular muscles. Invest Ophthalmol Vis Sci. 2010 Jul;51(7):3347-53.

4. Wong VA, Beckingsale PS, Oley CA, Sullivan TJ. Management of myogenic ptosis. Ophthalmology. 2002 May;109(5):1023-31.

5. Greaves LC, Yu-Wai-Man P, Blakely EL, et al. Mitochondrial DNA defects and selective extraocular muscle involvement in CPEO. Invest Ophthalmol Vis Sci. 2010 Jul;51(7):3340-6.

6. Wabbels B, Schroeder JA, Voll B, Siegmund H, Lorenz B. Electron microscopic findings in levator muscle biopsies of patients with isolated congenital or acquired ptosis. Graefes Arch Clin Exp Ophthalmol. 2007 Oct;245(10):1533-41.

7. Eshaghian J, Anderson RL, Weingeist TA, Hart MN, Cancilla PA. Orbicularis oculi muscle in chronic progressive external ophthalmoplegia. Arch Ophthalmol. 1980 Jun;98(6):1070-3.

8. Almousa R, Charlton A, Rajesh ST, Sundar G, Amrith S. Optimizing muscle biopsy for the diagnosis of mitochondrial myopathy. Ophthal Plast Reconstr Surg. 2009 Sep-Oct;25(5): 366-70.

9. Carta A, D'Adda T, Carrara F, Zeviani M. Ultrastructural analysis of extraocular muscle in chronic progressive external ophthalmoplegia. Arch Ophthalmol. 2000 Oct;118(10):1441-5.

10. Carta A, Carelli V, D'Adda T, Ross-Cisneros FN, Sadun AA. Human extraocular muscles in mitochondrial diseases: Comparing chronic progressive external ophthalmoplegia with leber's hereditary optic neuropathy. Br J Ophthalmol. 2005 Jul; 89(7):825-7. 